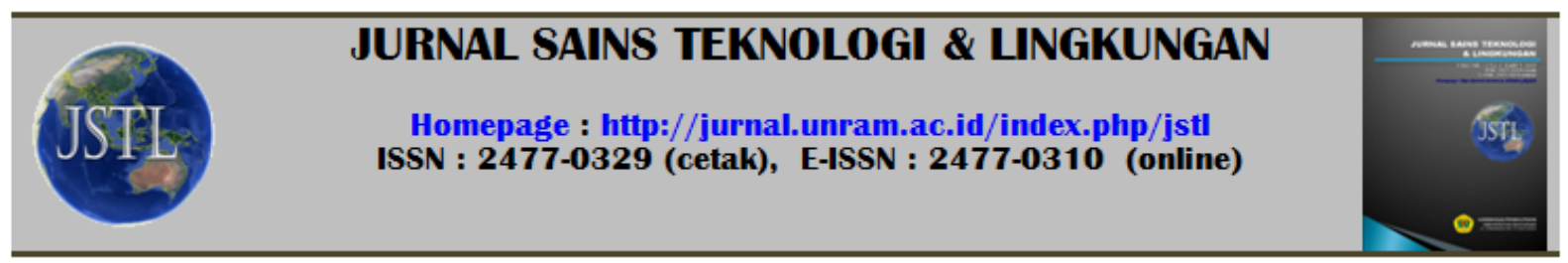

\title{
PEMANFAATAN SERAT TANDAN KOSONG KELAPA SAWIT (TKKS) DALAM PRODUKSI ETERNIT YANG RAMAH LINGKUNGAN
}

\begin{tabular}{|c|c|}
\hline & $\begin{array}{l}\text { 1)Tarkono } \\
{ }^{2} \text { ) Hadi Ali } \\
\left.{ }^{1}\right) \text { Jurusan Teknik Mesin Fakultas Teknik Universitas Lampung } \\
{ }^{2} \text { ) Jurusan Teknik Sipil Fakultas Teknik Universits Lampung }\end{array}$ \\
\hline Kata kunci : & Abstrak \\
\hline $\begin{array}{l}\text { eternit,serat, } \\
\text { TKKS }\end{array}$ & $\begin{array}{l}\text { Penelitian mengenai sifat fisis dan mekanik eternit berbasis serat tandan kosong kelapa sawit } \\
(\mathrm{TKKS}) \text { telah dilakukan. Pembuatan eternit berbasis serat TKKS merupakan usaha untuk } \\
\text { mengeliminir bahaya dari serat asbes yang persediaanya terbatas. Metode penyusunan serat } \\
\text { dengan variasi persentase serat } 5 \%, 10 \%, 15 \%, 20 \%, 25 \%, 30 \% \text { dan } 35 \% \text { terhadap vulume } \\
\mathrm{CaCO}_{3} \text { dan sebuk marmer. Dalam penelitian ini digunakan campuran serat TKKS, semen, } \\
\text { powder marmer dan batu kapur. Hasil pengamatan menunjukkan bahwa eternit berbasis } \\
\text { serat TKKS menghasilkan karakteristik beton serat pada kondisi optimum menghasilkan nilai } \\
\text { daya hantar panas }(\lambda)=0,623 \mathrm{kkal} / \mathrm{mh}^{\circ} \mathrm{C} \text {, kerapatan }(\rho)=1519 \mathrm{~kg} / \mathrm{cm}^{3} \text {, daya serap air }= \\
24,28 \% \text {, kekuatan lentur }=92,016 \mathrm{~kg}^{2} \mathrm{~cm}^{2} \text {. Penggunaan serat TKSS pada produksi eternit } \\
\text { memiliki potensi untuk diproduksi secara masal. Nilai daya hantar panas, kerapatan dan } \\
\text { daya serap air telah memenuhi standar eternit, sedangkan kuat lentur belum memenuhi } \\
\text { standar. }\end{array}$ \\
\hline
\end{tabular}

\begin{tabular}{|c|c|}
\hline Key words : & Abstract \\
\hline $\begin{array}{l}\text { eternit, fibre, } \\
\text { EFBP }\end{array}$ & $\begin{array}{l}\text { The research about mechanical and physical properties of eternit based on the empty fruit } \\
\text { bunch of palm (EFBP) was performed. Producing eternit based on the EFBP is in line with } \\
\text { the effort to overcome the negative effect of asbestos fibre that has limited resources. The } \\
\text { method of fiber with percentage of fiber variation are } 5 \%, 10 \%, 15 \%, 20 \%, 25 \%, 30 \% \text { and } \\
35 \% \text { to volume of CaCO }{ }_{3} \text { and dolosit powder. In this research, fibre from EFBP has been } \\
\text { mixed with calsit or dolosit powder and limestone to produce eternit. The result shows that } \\
\text { the eternit based on the EFBP is achieved the optimum condition of fiber concrete are } \\
\text { resulting the value of Thermal Conductivity }(\lambda)=0,623 \mathrm{kkal} / \mathrm{mh}^{\circ} \mathrm{C}, \text { Bulk Density }(\rho)=1519 \\
k \mathrm{~g} / \mathrm{cm}^{3} \text {, Water Absorption }(W A)=24,28 \% \text {, Modulus of Rupture }(\text { MOR })=92,016 \mathrm{~kg} / \mathrm{cm}^{2} \text {. } \\
\text { The use of EFBP based eternity has a potential for mass industrial production. The thermal } \\
\text { conductivity, bulk density and water absorption have fulfilled the quality standars of eternit, } \\
\text { while the flexural strength value have not fulfilled the standards. }\end{array}$ \\
\hline
\end{tabular}




\section{PENDAHULUAN}

Jumlah produksi kelapa sawit di Indonesia dari tahun ke tahun mengalami peningkatan, pada tahun 2010 mencapai 21.958.120 ton dan pada tahun 2011 mencapai 22.508.011 ton (BPS, 2012). Menurut Joko Supriyono (2013) selaku Sektretaris Jendral Gabungan Pengusaha Kelapa Sawit Indonesia (GAPKI) produksi kelapa sawit pada tahun 2013 sekitar 26 juta ton, sementara produksi kelapa sawit tahun 2014 diproyeksikan menjadi 28 juta ton, yang berarti naik 2 juta ton dari tahun 2013. Setiap produksi kelapa sawit menghasilkan limbah berupa tandan kosong kelapa sawit (TKKS) $23 \%$, cangkang $8 \%$, serat $12 \%$ dan limbah cair 66\% (Andriyati, 2007). Limbah TKKS pada tahun 2010 mencapai 5.050.367,6 ton dan pada tahun 2011 mencapai 5.176.842,53 ton (BPS, 2012). Ternyata limbah TKKS mengalami peningkatan seiring dengan meningkatnya produksi kelapa sawit secara nasional. Dengan meningkatnya limbah kelapa sawit tidak menutup kemungkinan akan terjadinya masalah lingkungan bagi mesyarakat sekitar pabrik kelapa sawit.

Upaya untuk menanggulangi masalah limbah pada pabrik kelapa sawit adalah dengan sistem pengolahan yang bersifat ramah lingkungan. Di PT Belitung Energy provinsi Bangka Belitung, sudah memanfaatkan TKKS sebagai bahan bakar pembangkit listrik. Saat ini hampir semua pabrik kelapa sawit telah memanfaatkan serabut dan cangkang kelapa sawit sebagai umpan bahan bakar boiler untuk pembangkit listrik. Berbeda dengan TKKS, sementara persentase limbah paling banyak dari kelompok limbah padat yang dihasilkan pabrik kelapa sawit berupa TKKS belum dapat dimanfaatkan secara optimal. Jumlah TKKS cukup besar karena hampir sama dengan jumlah produksi minyak sawit mentah (Wardani, 2012). TKKS yang tidak tertangani dapat menyebabkan bau busuk dan tempat bersarangnya serangga lalat. Untuk mengurangi dampak negatif dengan semakin banyaknya limbah dari pabrik kelapa sawit, maka dilakukan beberapa upaya untuk memanfaatkan TKKS. Usaha yang telah dilakukan dalam menanggulangi limbah TKKS adalah untuk pupuk organik, kemudian pemenfaatan yang lain sebagai bahan papan partikel karena TKKS memiliki potensi yang besar juga mengandung lignoselulosa.
Serat TKKS sebenarnya mengandung selulosa dan holoselulosa yang cukup tinggi sehingga layak dikembangkan dalam teknologi bahan, terutama bidang rekayasa beton. Efek penambahan serat TKKS dalam pembuatan bahan bangunan (beton) antara lain: ringan, kekuatan mekanik tinggi dan ramah lingkungan (Wismogroho, 2002). Serat ini juga berfungsi sebagai penguat serta meningkatkan kekuatan tarik agar lebih daktail dari pada beton pada umumnya. Beton biasanya bersifat getas, adanya serat sebagai penguat pada beton tersebut maka dapat mencegah terjadinya perambatan retakan akibat beban maupun panas hidrasi. Serat TKKS yang digunakan dalam pembuatan beton memberikan prospek dalam penyediaan bahan bangunan yang murah dengan memanfaatkan lokal resources yang ramah lingkungan (ecofriendly) (Gurning et al, 2013), bahan bangunan tersebut berupa eternit yang digunakan untuk plafon rumah.

\section{METODOLOGI PENELITIAN}

Pusat penelitian dilakukan di Laboratorium Material Jurusan Teknik Mesin Universitas Lampung. Sedangkan beberapa pengujian dilakukan di beberapa tempat, untuk pengujian kelenturan di Loratorium Analisis Struktur Jurusan Teknik Sipil Universitas Lampung. Sedangkan pengujian konduktivitas termal dilakukan di Laboratorium Pengujian Pusat Penelitian dan Pengembangan Permukiman Kementerian Pekerjaan Umum di Bandung.

Bahan utama eternit berupa semen portland, serbuk $\mathrm{CaCO}_{3}$, limbah gergajian batu marmer berupa powder, dan serat TKKS. TKKS dibuat serat pendek (dicacah $\pm 5 \mathrm{~cm}$ ) direndam dalam larutan $\mathrm{NaOH}$ dengan konsentrasi larutan $0 \%, 5 \%, 8 \%$ dan $10 \%$. Hasil rendaman dicuci kemudian dikeringkan pada terik matahari selama 1 hari. Semua bahan dicampur menjadi satu dengan ditambahkan air secukupnya sehingga berbentuk pasta dengan perbandingan : $25 \%$ semen portland, $25 \% \mathrm{CaCO}_{3}$, TKKS dan powder marmen divariasikan. Variasi persentase TKKS yang digunakan adalah 5\%, $10 \%, 15 \%, 20 \%, 25 \%, 30 \%$ dan $35 \%$, sementara powder marmer divariasikan $50 \%$, $45 \%, 35 \%, 30 \%, 25 \%, 20 \%$ dan $15 \%$. Dalam proses pencampuran ditambahkan air secukupnya dan diaduk sampai rata seperti adonan tembok. 
Proses pencetakan eternit dilakukan cetakan dengan cara menuangkan adonan ke dalam cetakan. Sebelum adonan dituangkan, cetakan dilumuri dengan oli bekas untuk menghindari kelengketan. Taburkan campuran semen dan batu kapur di atasnya secara tipis dan rata, kemudian dilakukan pengepresan dengan cara menggelindingkan alat pengepresan 1 kali di atas permukaan yang telah ditutup dengan tripleks dan kain kasur. Pemeraman dilakukan selama 3 (tiga) hari, pada tahap ini eternit dibolak balik dan disiram dengan air untuk menghindari keretakan akibat pengeringan yang terlalu cepat. Untuk mengetahui karakteristik dari eternit yang digunakan sebagai plafon maka perlu diperhatikan beberapa hal antara lain sifat mekanik dan sifat fisik material tersebut. Untuk itu maka dilakukan dengan pengujian konduktivitas termal, daya serap air dan kelenturan eternit.

\section{HASIL DAN PEMBAHASAN}

Salah satu usaha menanggulangi bahaya limbah pabrik kelapa sawit adalah dengan melakukan pengolahan dan penanganan limbah secara menyeluruh. Penanganan limbah yang tidak tuntas akan berpotensi terjadinya pencemaran di lingkungan penghasil limbah. Pemanfaatan TKKS sejauh ini sebagian besar sebagai bahan organik seperti briket, pakan ternak dan pupuk mulsa. Serat TKKS sebenarnya mengandung selulosa dan holoselulosa yang cukup tinggi sehingga layak dikembangkan dalam teknologi bahan, terutama bidang rekayasa beton.

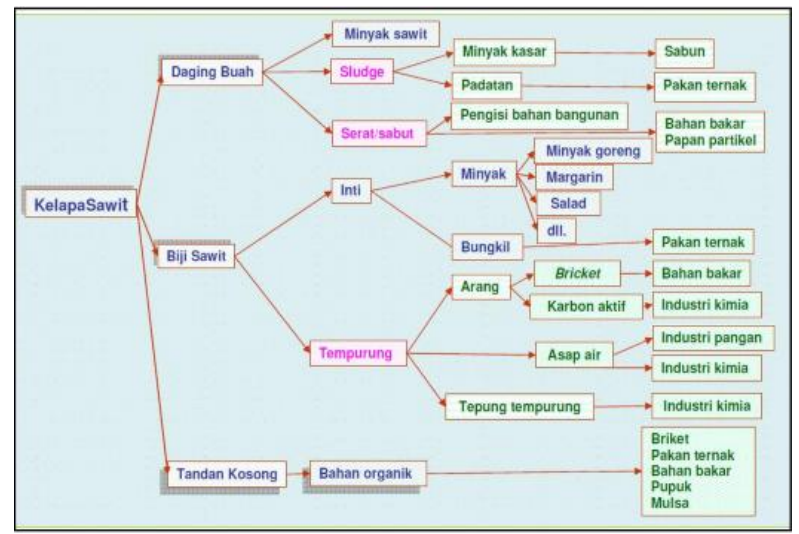

Sumber : Direktoran Jenderal Pengolahan Hasil Pertanian, 2006

Gambar 1. Pohon industri Pemanfaatan limbah kelapa sawit
Efek penambahan serat TKKS dalam pembuatan bahan bangunan (beton) antara lain: ringan, kekuatan mekanik tinggi dan ramah lingkungan (Wismogroho, 2002). Serat ini juga berfungsi sebagai penguat serta meningkatkan kekuatan tarik agar lebih daktail dari pada beton pada umumnya. Beton biasanya bersifat getas, adanya serat sebagai penguat pada beton tersebut maka dapat mencegah terjadinya perambatan retakan akibat beban maupun panas hidrasi. Serat TKKS yang digunakan dalam pembuatan beton memberikan prospek dalam penyediaan bahan bangunan yang murah dengan memanfaatkan lokal resources yang ramah lingkungan (eco-friendly) (Gurning et al, 2013). Dalam rangka menganalisa kemungkinan/peluang pemanfaatan serat TKKS sebagai bahan penguat eternit maka perlu dilihat beberapa sifat mekaniknya.

\section{Daya serap air eternit berserat TKKS}

Daya serap air merupakan sifat fisis papan semen yang menunjukkan kemampuan papan untuk menyerap air selama 24 jam. Hasil pengujian daya serap air papan semen berserat TKKS yang dihasilkan pada penelitian ini disajikan pada gambar 2 .

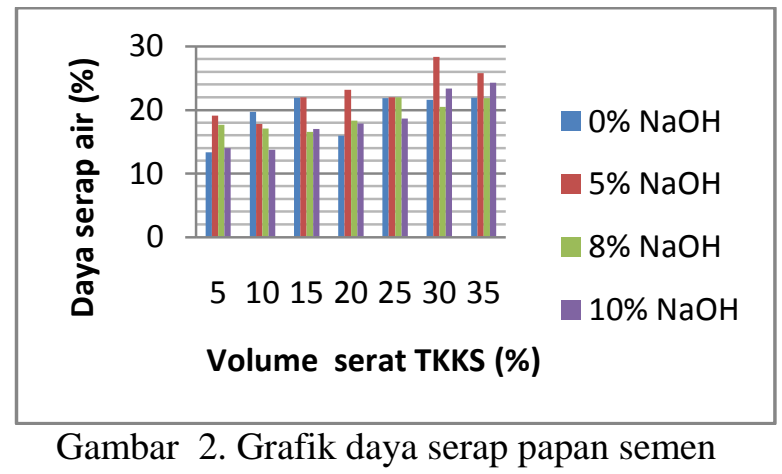
(eternit) berserat TKKS

Hasil pengujian daya serap air selama 24 jam papan semen (eternit) berserat TKKS dengan persentase serat $5 \%$ mengalami peningkatan seiring dengan penambahan volume serat sampai 35\%. Daya serap air terendah adalah $13,23 \%$ terjadi pada papan semen (eternit) berserat TKKS sebanyak 5\% dan daya serap air tertinggi adalah $27,35 \%$ terjadi pada eternit berserat TKKS sebanyak $30 \%$. Hal ini dipengaruhi oleh nilai kerapatan yang cukup tinggi pada eternit sehingga menyebabkan eternit lebih padat dan sulit menyerap air. Pada eternit dengan 5\% serat TKKS kerapatannya 
lebih tinggi dibandingkan dengan eternit yang berserat 30\%. Fatriasari dan Hermiati (2006) dalam Sibarani (2011) menyatakan bahwa besarnya nilai daya serap air dipengaruhi besarnya diameter serat dan panjang serat partikel bambu yang digunakan. Semakin besar ukuran diameter dan panjang serat partikel yang digunakan maka nilai pengembangan tebalnya juga akan semakin besar.

Jumlah serat yang relatif besar biasanya akan membentuk struktur papan semen yang kurang padat sehingga menyebabkan adanya rongga di dalam papan semen yang memudahkan penyerapan air. Namun senyawa semen dapat menutupi permukaan serat dapat mengghambat penyerapan air sehingga pada papan semen dengan rendaman serat pada $\mathrm{NaOH} 5 \%$ maupu $8 \%$ tidak terlalu terjadi perbedaan yang signifikan. Sebab serat yang telah terbebas dari pengeruh zat lemak akan mudah terjadi ikatan yang kuat dengan semen. Pada standar JIS A 5417-1992 tidak menetapkan nilai daya serap air yang dapat diterima sesuai standar.

Untuk lebih memperjelas dalam mengamati pengaruh rendaman serat pada larutan $\mathrm{NaOH}$ maka dapat dilihat pada gambar 3.

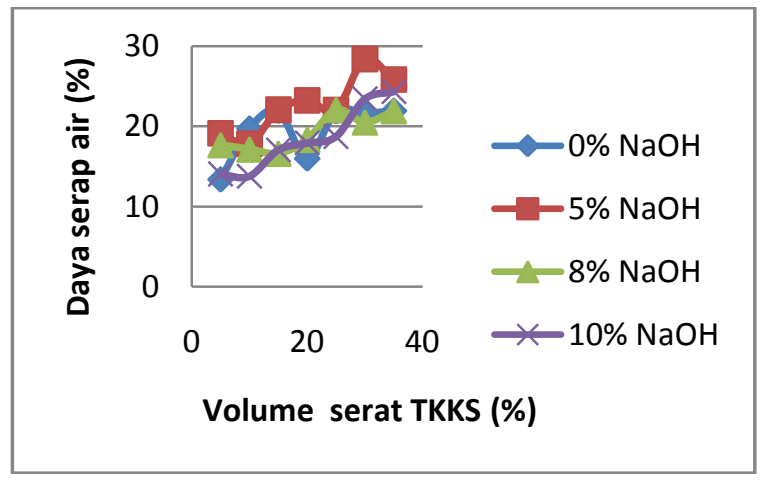

Gambar 3. Grafik daya serap eternit berserat

TKKS dilihat berdasarka rendaman $\mathrm{NaOH}$

Secara umum terjadi kenaikan daya serap air seiring dengan bertambahnya serat TKKS dalam eternit. Hal ini disebabkan semakin banyaknya serat TKKS dalam eternit peluang terjadinya rongga antara serat dengan matriknya semakin besar, walaupun dalam proses pembuatannya campuran antara serat dengan matrik diusahakan serata mungkin. Dari 4 variasi perendaman serat pada larutan $\mathrm{NaOH}$ menunjukkan bahwa eternit dengan serat TKKS yang direndam $8 \%$ larutan $\mathrm{NaOH}$ sangat bagus, hal ini dibuktikan kenaikan daya serapnya tidak terlalu tinggi sehingga jika diaplikasikan sebagai plafon akan sangat cocok.

\section{Kerapatan eternit berserat TKKS}

Kerapatan menunjukan banyaknya massa per satuan volume. Sifat-sifat papan yang dihasilkan sangat dipengaruhi oleh kerapatan. Selain itu kerapatan juga menjadi dasar pertimbangan penggunaan suatu produk. Hasil pengujian kerapatan eternit berserat TKKS yang dihasilkan pada penelitian ini disajikan pada gambar 4.

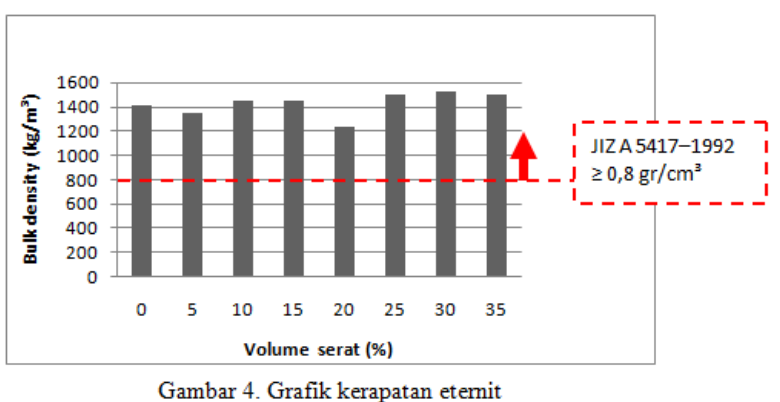

Hasil pengujian kerapatan eternit dengan $20 \%$ serat merupakan jenis campuran yang paling kecil kerapatannya yaitu 1233,7 $\mathrm{kg} / \mathrm{m}^{3}$, sedangkan dengan campuran $30 \%$ serat TKKS kerapatannya $1519 \mathrm{~kg} / \mathrm{m}^{3}$. Secara umum terlihat bahwa seiring dengan bertambahnya volume serat kerapatannya semakin besar yang berarti ikatan antara matrik dengan serat semakin baik. Hal ini bertentangan dengan penelitian yang dilakukan oleh Mujtahid (2010) yang menyatakan bahwa ukuran partikel yang besar memiliki kerapatan yang rendah karena partikel dengan ukuran yang besar dapat mengakibatkan kontak yang lemah antara partikel dan semen sehingga menciptakan adanya rongga diantara partikel-partikel tersebut. Perbadaan ini sianggap wajar sebab kedua penelitian menggunakan penguat yang berbeda yaitu serat TKKS dan serbuk batang aren.

Secara umum bahwa kerapatan papan semen berserat TKKS yang dibuat dalam penelitian ini menunjukkan nilai yang lebih tinggi dibandingkan dengan standar yang ada. Artinya eternit yang dibuat menggunakan penguat serat TKKS dengan volume sampai 35\% masih memenuhi standar JIS A 5417-1992 yang dipersyaratkan yaitu $\geq 0,8 \mathrm{~g} / \mathrm{cm} 3$. Dengan 
demikian bahwa eternit tersebut dapat diaplikasikan sebagai plefon rumah tinggal.

\section{Konduktivitas termal eternit berserat TKKS}

Konduktivitas panas suatu bahan adalah ukuran kemampuan bahan untuk menghantarkan panas (termal) (Isaacs dan Alan, 1994). Berdasarkan pengolahan data diperoleh nilai konduktivitas termal rata-rata untuk setiap benda uji. Hasil pengujian tersebut menunjukkan bahwa nilai konduktivitas termal eternit untuk masing-masing variasi serat TKKS adalah 0,435 $\mathrm{kcal} / \mathrm{mh}^{\circ} \mathrm{C}$ hingga $0,623 \mathrm{kcal} / \mathrm{mh}^{\circ} \mathrm{C}$. Dari nilai konduktivitas termal tersebut dapat digambarkan dalam bentuk grafik seperti pada gambar 5 .

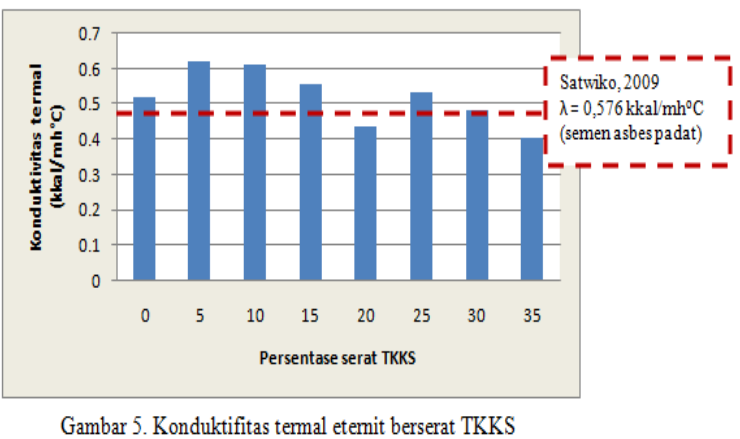

Dari Gambar 5 menunjukkan bahwa semakin banyak kandungan kertas pada bata kertas maka nilai konduktivitas termal semakin rendah. Sesuai dengan literatur bahwa bahan yang memiliki nilai konduktivitas tinggi maka tergolong sebagai bahan yang konduktor yaitu penghantar panas yang baik, sedangkan yang memiliki nilai konduktivitas rendah disebut bahan yang isolator yaitu penghantar panas yang buruk. Sementara nilai konduktivitas untuk semen asbes padat adalah $0,576 \mathrm{kkal} / \mathrm{mh}^{\circ} \mathrm{C}$ dan konduktivitas batu bata ringan $0,806 \mathrm{kkal} / \mathrm{mh}^{\circ} \mathrm{C}$ (Satwiko, 2009). Dari data terlihat bahwa eternit berserat TKKS memiliki konduktivitas termal lebih rendah dibandingkan dengan batu bata ringan. Dengan demikian dapat disimpulkan bahwa eternit berserat TKKS merupakan material yang memiliki konduktivitas termal jelek. Maka eternit berserat TKKS tersebut bagus jika digunakan untuk plafon bangunan karena panas udara dari atap rumah tidak akan mudah dihantarkan ke dalam ruangan.

Namun dari penelitian ini ada beberapa eternit dengan campuran serat TKKS memiliki nilai konduktivitas termal lebih tinggi dari literatur. Literatur menunjukkan bahwa konduktivitas termal semen asbes padat adalah $0,576 \mathrm{kkal} / \mathrm{mh}^{\circ} \mathrm{C}$. Eternit dengan serat TKKS sebanyak $5 \%$ memiliki nilai konduktivitas termal sebesar $0,623 \mathrm{kkal} / \mathrm{mh}^{\circ} \mathrm{C}$ dan 0,612 $\mathrm{kkal} / \mathrm{mh}^{\circ} \mathrm{C}$ pada campuran serat TKKS sebanyak 10\%. Akan tetapi jika serat TKKS diperbanyak sampai 35\% maka nilai konduktivitas termalnya dibawah semen asbes padat. Hal ini menandakan bahwa serat TKKS merupakan jenis material yang yang bersifat sebagai isolator.

\section{Kekuatan tarik eternit berserat TKKS}

Hasil uji kekuatan tarik belah berdasarkan umur campuran ditampilkan pada gambar 6 dan gambar 7 berikut ini.

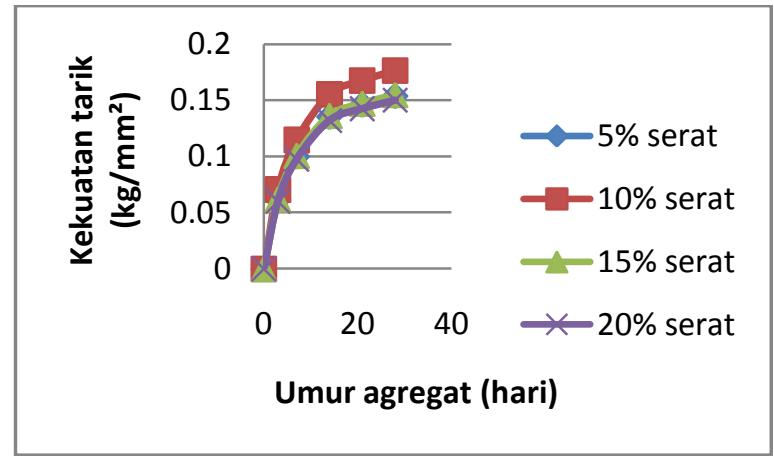

Gambar 6. Grafik hubungan antara umur agregat dengan kekuatan tarik belah dengan konsentrasi serat (5\% s.d. $20 \%)$

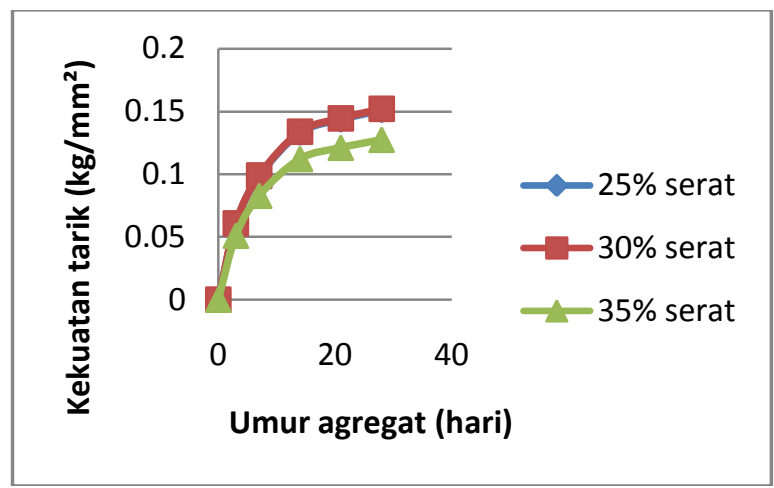

Gambar 7. Grafik hubungan antara umur agregat dengan kekuatan tarik belah dengan konsentrasi serat $(25 \%$ s.d. $35 \%)$

Dari kedua grafik di atas terlihat bahwa kondisi optimum penambahan serat TKKS pada eternit tercapai pada prosentase $10 \%$. Dengan kata lain sejauh ini komposisi yang paling ideal campuran serat tkks adalah sebesar 10\%. Kekuatan tarik eternit berserat TKKS masih tergolong rendah. Rendahnya kekuatan tarik pada eternit berserat TKKS disebabkan penyusun utama dari eternit 
bersifat getas. Walaupun eternit dalam penelitian ini menggunakan penguat dari serat TKKS masih bersifat getas. Matrik eternit terbuat dari bahan utama berupa semen portland, bahan tersebut jika direaksikan dengan air maka akan mengeras dengan sendirinya. Sejak munculnya bahan bangunan berupa eternit, sebenarnya telah diberi serat yaitu asbes. Namun serat asbes sangat berbahaya bagi orang yang menghirupnya, sebab akan menimbulkkan penyakit.

\section{Keteguhan patah (MOR) eternit berserat TKKS}

Keteguhan patah (MOR) adalah nilai ukuran kekuatan lentur statis kayu yang menunjukan beban maksimum yang dapat ditahan oleh papan partikel per satuan luas hingga papan tersebut patah.

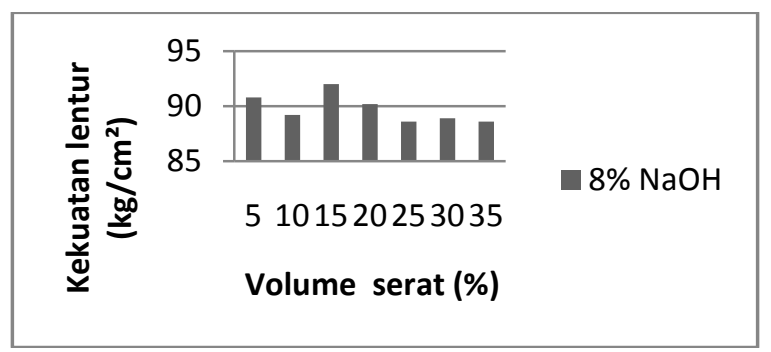

Gambar 8. MOR eternit berserat TKKS

Dari grafik di atas terlihat bahwa kuat tekan terendah dari eternit berserat TKKS adalah $88,65 \mathrm{~kg} / \mathrm{cm}^{2}$ pada eternit dengan campuran $25 \%$ serat dan kuat tekan tertinggi terjadi pada campuran $15 \%$ eternit yaitu $92,02 \mathrm{~kg} / \mathrm{cm}^{2}$. Artinya secara keseluruhan eternit yang dibuat dalam penelitian ini masih memiliki kuat lentur yang relatif rendah. Dari hasil penelitian yang telah dilakukan McBride dan Shuka tahun 2002 menunjukkan bahwa beton dengan penambahan serat TKKS sebanyak 10 - $30 \%$ (berat) semen dengan umur 28 hari menghasilkan kuat tekan sekitar 0,9 - 2,3 MPa. Sedangkan nilai kuat tekan tanpa penambahan serat adalah sebesar 7,2 Mpa (McBride dan Shukla, 2002), nilai ini relatif lebih tinggi bila dibandingkan dari beton serat yang telah dibuat. Penggunakan serat bambu sebanyak $0,5-1,5 \%$ (berat) semen dan panjang serat yang digunakan $1-2 \mathrm{~cm}$, menghasilkan kuat tekan sebesar 33 - $46 \mathrm{MPa}$, artinya beton serat bambu relatif lebih kompetitif bila dilihat dari karakteristiknya (Gurning et al, 2013). Hasil lain bahwa kuat tekan dengan menggunakan bahan adif adalah ceramics microspere berkisar 15 - $21 \mathrm{MPa}$, dan nilai ini sangat dipengaruhi ukuran butir dalam orde mikro (Teo et al, 2002).

\section{KESIMPULAN}

Daya serap air dari eternit berbasis TKKS akan bertambah besar seiring dengan bertambahnya volume serat. Sementara kerapatannya cukup bagus yaitu rata-rata lebih besar dari standar JIS A 5417-1992 yang dipersyaratkan yaitu $=0,8 \mathrm{~g} / \mathrm{cm}^{3}$. Konduktivitas termal eternit lebih rendah dari semen asbes padat $\lambda=0,576 \mathrm{kkal} / \mathrm{mh}^{\circ} \mathrm{C}$, artinya eternit hasil penelitian ini layak diaplikasikan sebagai plafon rumah. Kekuatan lentur eternit rata-rata masih rendah dengan kata lain eternit ini mudah patah.

\section{DAFTAR PUSTAKA}

Andriyati A.H., 2007, Pemanfaatan Limbah Tandan Kosong Kelapa Sawit Untuk Papan Serat Semen, Jurnal Permukiman Volume 2 No. 3 Desember 2007.

BPS, 2012, Indonesia Dalam Angka, Badan Pusat Statistik Republik Indonesia, Jakarta.

Direktoran Jenderal Pengolahan Hasil Pertanian, 2006, Pedoman Pengelolaan Limbah Industri Kelapa Sawit, Departemen Pertanian, Jakarta.

Gurning, N., A.P.Tetuko, dan P. Sebayang, 2013, Pembuatan Beton Serat Tandan Kosong Kelapa Sawit, TELAAH Jurnal Ilmu Pengetahuan dan Teknologi, Akreditasi LIPI Nomor :377/E/2013

Isaacs, dan Alan, 1994, Kamus Lengkap FISIKA, Erlangga.

Japanese Standarts Association (JSA), 1992, Japanese Industrial Standarts JIS A 5417 : 1992, Cementboards Japan : Japanese Standarts Association.

McBride, S.P., and A. Shukla, 2002, Processing and characterization of a lightweight concrete using cenospheres, Journal Of Materials Science 37.

Mujtahid, 2010, Pengaruh Ukuran Serbuk Aren Terhadap Kekuatan Bending Densitas dan Hambatan Panas Komposit SemenSerbuk Aren, Skripsi, Universitas Sebelas Maret, Surakarta.

Satwiko, P., 2009, Fisika Bangunan, Penerbit Andi, Yogyakarta.

Sibarani, I.P., 2011. Karakteristik Papan Semen dari Tiga Jenis Bambu dengan 
Penambahan Katalis Magnesium Klorida (MgCl2), Skripsi, Medan.

Supriyono J., 2013, Press Conference Refleksi

Industri Sawit Tahun 2013 dan Prospek

Tahun 2014 di Jakarta, Rabu (15/1),

Harian Ekonomi NERACA.

Teo, D.C.L., M.A. Manan, and V.J. Kurian, 2002, Structural Concerete using Oil Palm Shell (OPS) as Lightweight Agregate, University Malaysia Sabah, Civil Engineering Program, SabahMalaysia.

Wismogroho, A., 2002, The Use of Natural Fibre Reinforced Composites in Building Materials, ProceedingsInternational Symposium; Building Research and The Sustainability of The Built Environment in The Tropics, Tarumanagara University Indonesia. pp. 598-610 9.

Wardani, D.I., 2012, Tandan Kosong Kelapa Sawit (TKKS) Sebagai Alternatif Pupuk Organik, Jurnal Lingkungan Hidup Bumi - Lestari Bumi Bebas Polusi, https://uwityangyoyo.wordpress.com/20 12/01/04. 